\begin{tabular}{lllll} 
ZAPISKI HISTORYCZNE & $-\underset{\text { Teszyt } 2}{\text { TOM }}$ & LXXX & - ROK 2015 \\
\hline
\end{tabular}

http://dx.doi.org/10.15762/ZH.2015.23

SEWERYN SZCZEPAŃSKI

(Ośrodek Badań Naukowych im. Wojciecha Kętrzyńskiego w Olsztynie)

\title{
ŚWIĘTA WOJNA (NIE TYLKO) W ŚWIETLE ARCHEOLOGII*
}

W 2013 r. wydawnictwo Routledge wydało książkę autorstwa Aleksandra Pluskowskiego pt. The Archaeology of the Prussian Crusade: Holy War and Colonization. Autor, wykładowca na Uniwersytecie w Reading, należy do młodej generacji badaczy, którego szczególne zainteresowania skupiają się na problematyce średniowiecznej Europy, a w ostatnim czasie także Prus. Ważne miejsce w badaniach A. Pluskowskiego zajmuje też archeozoologia. Objawia się to w jego licznych publikacjach oraz prowadzonych projektach ${ }^{1}$. W kontekście Prus, jak i recenzowanej książki na szczególną uwagę zasługuje projekt „The Ecology of Crusading: The Environmental Impact of Conquest, Colonisation and Religious Conversion in the Medieval Baltic”, realizowany w latach 2010-2014 przez międzynarodowy zespół badaczy z Wielkiej Brytanii, Polski, Łotwy, Estonii i Czech².

Wspomnienie o projekcie wydaje się o tyle ważne, że jego powiązanie z książką jest bardzo wyraźne. We wstępie (Preface and Acknowledgments, s. XIII-XIV) autor zaznacza, że ideą dla napisania pracy była chęć rozwinięcia wcześniej podejmowanych badań związanych $\mathrm{z}$ wykopaliskami na zamku w Malborku, z których pozyskano liczne fragmenty faunistyczne oraz archeozoologiczne. Dane te pozwoliły dojść do wniosku, jak ważna byłaby synteza ujmująca szerokie zagadnienia podboju, kolonizacji i procesów nawracania, na którą spojrzałoby się przez pryzmat nauk historycznych i przyrodniczych. Podobne założenia w szerokim kontekście Prus przyświecają także projektowi, co może tylko wskazywać, jak ważne jest to zagadnienie dla autora i jak istotne - miejmy nadzieję - wnioski projekt ten może przynieśćs

\footnotetext{
* Uwagi na marginesie książki Aleksandra Pluskowskiego, The Archaeology of the Prussian Crusade: Holy War and Colonisation, Routledge, Abingdon (London-New York) 2013, ss. XIX + 428, 84 il., ISBN 978-0-415-69171-0 (oprawa miękka).

1 Curriculum vitae autora $\mathrm{z}$ aktualną listą publikacji znajdujemy na stronie Uniwersytetu w Reading: https://www.reading.ac.uk/archaeology/about/staff/a-g-pluskowski.aspx (dostęp z 15 IX 2015 r.).

${ }^{2}$ http://www.ecologyofcrusading.com (dostęp z 15 IX 2015 r.).

${ }^{3}$ Część wyników badań jest na bieżąco publikowana na stronie projektu. Tam też znajduje się bibliografia prac powstałych w jego ramach. W 2015 r. ukazało się także pięć artykułów projektowych stanowiących odrębny dział (Ekologia krucjat. Wstępne wyniki polskiej części projektu, s. 158-223)
} 
Recenzowana publikacja pod względem edytorskim została przygotowana bardzo starannie. Na 428 stronach znajdziemy osiem rozdziałów oraz obszerną rekapitulację. Ponadto zamieszczono tu czarno-białe fotografie, ryciny, mapy. Rozdziały podzielone są na zagadnienia tematyczne. Po wstępie i opisaniu chronologii oraz źródeł autor przechodzi do opisu społeczeństwa Prus przedchrześcijańskich. Kolejny rozdział dotyczy podboju i początków kolonizacji Prus. Rozdział czwarty poświęcony jest procesowi umacniania się władztwa krzyżackiego w Prusach i Inflantach oraz budowy sieci zamków. W kolejnym rozdziale autor roztacza przed czytelnikiem swoją wizję tworzenia miast i ich uczestnictwa $\mathrm{w}$ międzynarodowym handlu. Zagadnieniom nawracania ludności autochtonicznej i problematyce utrzymywania się wśród niej reliktów pogaństwa poświęcony jest rozdział szósty. Najbardziej wartościowym rozdziałem tej książki wydaje się rozdział siódmy, przedostatni, dotyczący problematyki zmian w środowisku naturalnym, które towarzyszyły kolonizacji krzyżackiej ${ }^{4}$. Książka kończy się nieco przydługim i - zastanawiam się, czy rzeczywiście ważnym w kontekście całej rozprawy - rozdziałem opisującym w zbyt licznych dywagacjach to, co po średniowiecznych Prusach zachowało się do dziś. Na końcu znajdujemy trafne konkluzje, dodatkowo spis literatury i źródeł oraz - co w książkach naukowych zawsze jest niezwykle przydatne - indeks.

Po tej krótkiej charakterystyce ogólnej przejdźmy do bardziej szczegółowego opisu. Książka doczekała się co prawda już wielu pozytywnych recenzji ${ }^{5}$, jednakże ich autorom nie zawsze udawało się uwypuklić pewne braki, nieścisłości, błędy i potknięcia językowe. Postarajmy się więc prześledzić całość, głównie w kontekście zagadnień związanych z Prusami oraz zakonem krzyżackim.

W liczącym zaledwie dwie strony wstępie $3 / 4$ treści zajmują podziękowania. Znacznie przeważają one nad informacjami na temat metodyki, kwestionariusza badawczego i szerszego omówienia celu pracy oraz charakterystyki bazy źródłowej. Te znajdujemy nieco dalej. Przykładowo w podrozdziale Terminology and Glossary (s. XV-XIX) autor wyjaśnia zasady stosowania w książce zapisów nazw regionów, miast oraz wybranych terminów, które w różnych opracowaniach i źródłach występują w często odmiennych wariantach językowych. Chcąc ułatwić zrozumienie, stosuje on zestandaryzowany zapis angielski, aczkolwiek Teutonic Knights lub Teutonic Order, w skrócie The Order, obok zapisu Order's state miesza się nierzadko

w pracy zbiorowej: Materiały do archeologii Warmii i Mazur, red. Mirosław Hoffmann, Maciej KARCZEWSKI, Sławomir WADYL, Białystok-Gdańsk-Olsztyn 2015.

${ }^{4}$ We współautorstwie z Alexandrem Brownem.

${ }^{5}$ Darius von Guttner-Sporzynski, Journal of the Australian Early Medieval Association, vol. 10: 2014, s. 125-127; David Gaimster, The Antiquaries Journal, vol. 93: (September) 2013, s. 442-444; Denis Pringle, Antiquity. A Review of World Archaeology, vol. 87 (338): (December) 2013, s. 1242-1244; Barbara BомвI, The Medieval Review, 2014 (18 IX 2014 r.), http://scholarworks. iu.edu/journals/index.php/tmr/article/view/18661/24774 (dostęp z 15 IX 2015 r.); David S. BARACH, Michigan War Studies Review (4 VI 2013 r.), http://www.miwsr.com/2013-042.aspx (dostęp z 15 IX 2015 r.). 
z niemieckim Ordenstaat. Nie stwarza to problemu, a jest przy okazji dość eleganckim wybiegiem semantycznym.

Więcej problemów może czytelnikowi przysporzyć zrozumienie zasad stosowania nazw regionów, miast etc. (s. XVI-XIX). Autor, trzymając się wariantu angielskiego jako dominującego $\mathrm{w}$ książce, słusznie dokonuje zestawienia poszczególnych nazw w językach niemieckim, polskim i właśnie w angielskim. Brak jednak wśród regionów zajętych przez zakon krzyżacki w XIII-XV w. Żmudzi. Powinniśmy do 16 nazw dodać zatem „Samogaiten - Żmudź - Samogitia”. Nawet jeżeli według autora jest to obszar nie tyle pruski, co litewski - podobnie jak region kłajpedzki (Klaipeda Region), historyczny Memelland, o którym autor wspomina - to warto byłoby chociażby wspomnieć o tym czytelnikowi. Jest rzeczą oczywistą i znaną również autorowi, że Żmudź należała do Zakonu, widzimy ją na stosownej mapie 1.2 (s. 2) i wspomina się też o jej podboju (s. 15-16). Podobnie można zauważyć pewne nieścisłości w przypadku nazw miast i zamków. Nie ma tu choćby polskich odpowiedników podczas podawania niemieckich nazw, takich jak: Balga (pol. Bałga), Brandenburg (Pokarmin), Fischhausen (Rybaki), Kreuzburg (Krzyżbork), Ragnit (Ragneta), Tilsit (Tylża). Są to nazwy historyczne, używane powszechnie w polskich źródłach. Nie ma też rozróżnienia, czy Eylau to dawne Deutsch-Eylau (obecna Iława), czy Preussisch-Eylau (obecny Bagrationowsk).

Autor tłumaczy również wybrane terminy jednostek administracyjnych oraz funkcji w zakonie krzyżackim. Brak tu jednak angielskich odpowiedników takich pojęć jak Kämmerer - komornik (ten pojawia się dopiero na stronie 142) czy Kapitel - kapituła, choć niżsi urzędnicy tacy jak wójtowie czy prokuratorzy zostali w zestawieniach ujęci.

We wstępie w pierwszym podrozdziale Historical Frameworks and Sources (s. 1-9) autor przedstawia źródła idei wypraw krzyżowych nad Bałtyk oraz udziału w nich zakonu krzyżackiego. Nie omija też początków historii Zakonu. Czytając w tytule podrozdziału o „źródłach”, czytelnik może się czuć nieco zawiedziony. Mamy tu bowiem jedynie omówienie badań nad regionem nadbałtyckim w średniowieczu, przegląd dorobku ważniejszych badaczy i instytucji prowadzących badania nad Prusami oraz zakonem krzyżackim w Niemczech, Polsce, Rosji i krajach bałtyckich. Znacznie więcej informacji na temat źródeł pisanych, ikonograficznych i archeologicznych znajdujemy na stronach 24-42 (do tego problemu jeszcze wrócimy). O procesie chrystianizacji tego regionu przed przybyciem Krzyżaków, następnie podboju Prus i uczestnikach walk z Bałtami oraz powstań przeciwko Zakonowi czytamy w podrozdziałach: Holy War in the Baltic (s. 10-11); The Teutonic Order in Prussia (s. 11-13); Consolidating of early Crusade (s. 13-15); The Conquest of Sambia and the Great Prussian Uprising (s. 15-17). Autor konsekwentnie używa zapisu „Krucjata” wielką literą, uważając ją za zjawisko historyczne, którego znaczenie tłumaczy we wstępie (s. XVI). Na stronie 14 pisze o pierwszym powstaniu Prusów. Wśród walczących z Krzyżakami Warmów i Natangów wymienia też Bartów zamiast Pomezanów. O ich udziale w powstaniu lat 1242-1249 wiadomo 
na podstawie treści traktatu dzierzgońskiego z 1249 r. Autor najpewniej pomylił tu wydarzenia z 1242 r. z opisanym przez Dusburga sojuszem Warmów, Natangów i Bartów w czasie oblężenia Bałgi w 1237 r. ${ }^{6}$ Nieco na wyrost wydaje się stwierdzenie, że sukces militarny zakonu krzyżackiego wiązał się z lepszym uzbrojeniem, szczególnie używaniem ciężkich koni bojowych, kuszy oraz dużej dyscypliny wojskowej na polu bitwy. To nic innego, jak przeniesienie realiów końca XIII w. i XIV-XV w. na czas podboju, kiedy nie sami Krzyżacy, ale ich sojusznicy - fakt, krzyżowcy! - stanowili główną siłę w podboju ziem pruskich. Z drugiej strony, czy trwający pięćdziesiąt lat podbój Prusów (co autor podnosi na stronie 17), przerywany licznymi powstaniami, można nazwać wielkim sukcesem? Zabrakło w opisie tego „sukcesu” postaw Prusów, którzy obrali drogę współpracy z Krzyżakami, a o których źródła informują bardzo często.

W momencie ustabilizowania swojej pozycji w Prusach i Inflantach zakon krzyżacki mógł w kolejnych dekadach rozbudowywać swoją potęgę. Zgodnie z tym autor opisuje dalsze postępy rozwoju władztwa krzyżackiego nad Bałtykiem przez aneksję Gdańska i Pomorza Gdańskiego (The War in Pomerania and the Annexion of Gdańsk [Danzig], s. 17-18) oraz wojny z Litwą w XIV w. (The Ordensstaat and the "Eternal Crusade” against Lithuania in the Fourteen Century, s. 18-20) i Polską w XV i XVI stuleciu (The War with Poland and the End of the Ordensstaat, s. 20-23).

Wspomniano, że uwagę analizie źródeł dotyczących Prus autor poświęcił nie tyle w podrozdziale Historical Frameworks and Sources, co w dalszej części wstępu. I tu przedstawia szereg źródeł pisanych, począwszy od źródeł narracyjnych, skończywszy na źródłach dokumentowych, kartograficznych i innych. Nie może być zarzutem, że spis jest niekompletny, bo to wymagałoby wręcz oddzielnej monografii, wypada natomiast zwrócić uwagę, że wbrew temu, co autor pisze na stronach 2526, kronika Szymona Grunaua nie doczekała się polskiej edycji („Grunau’s work is available in both German and Polish"), a powoływanie się na pracę Sławomira Zonenberga wskazuje, że A. Pluskowski niestety się z nią nie zapoznał, bo wiedziałby, że nie jest to wydanie kroniki, ale studium źródłoznawcze jej poświęcone ${ }^{7}$. Autor analizuje także szereg zabytków artystycznych powstałych w kręgu pruskim (s. 28-31), źródeł archeologicznych (s. 31-42) oraz skupia się na perspektywach badań interdyscyplinarnych (s. 40-42). Słusznie zauważa, że badania nad klasyfikacją zabytków i stanowisk w Prusach nadal są na etapie rozwoju, wzbudzając wiele sporów. Taką kontrowersją może być także opisane przez autora znalezisko bagienne z Drwęcka (dawne Dröbnitz, powiat ostródzki/Osterode). Autor wspomina o owym odkryciu z 1939 r., kiedy podczas kopania torfu natrafiono na ciało kobiety, które po przewiezieniu do Królewca zinterpretowano jako pochodzące

${ }^{6}$ Por. Preußisches Urkundenbuch (dalej cyt. PrUb.), Bd. 1, H. 1, hrsg. v. Rudolf PhiLIPPI, Königsberg 1882, Nr. 218; Petrus De Dusburg, Chronicon terrae Prussiae, ed. Jarosław Wenta, Sławomir WyszoMIRSKi (Pomniki Dziejowe Polski. Seria 2, t. 13), Kraków 2007, lib. III, cap. 26.

${ }^{7}$ Sławomir Zonenberg, Kronika Szymona Grunaua, Bydgoszcz 2009. 
z wczesnej epoki żelaza. A. Pluskowski nieco na wyrost podważył jednak ustalenia niemieckich badaczy. Powołując się na artykuł Mirosława J. Hoffmanna ${ }^{8}$, stwierdził kategorycznie, że nie są to szczątki z wczesnej epoki żelaza, ale ciało ofiary morderstwa z końca XIX w. (s. 35-36). Zapomniał jednak dodać, że M.J. Hoffmann w swojej pracy z 2009 r. oraz jednej z wcześniejszych ${ }^{9}$ wcale tak kategoryczny w swoich wnioskach nie był, a ewentualność odmłodzenia znaleziska traktował wyłącznie jako ciekawostkę. Jak czytamy w obu jego artykułach: w 1965 r. w liście do pisma „Osteroder Zeitung” (Nr. 23) jeden z czytelników napisał, jakoby miała to być niejaka Baranowska - wątła kobieta, zabita około 1890 r. przez swojego męża choleryka. Autor listu powoływał się na relację swojego... dziadka (!), że Baranowska zaginęła, a jej ciała nie znaleziono, stąd też zwykła plotka połączyła jej zniknięcie ze znaleziskiem bagiennym w Drwęcku. Czytelnik zatem, zaznajamiając się z informacjami A. Pluskowskiego o rzekomej dziewiętnastowiecznej chronologii znaleziska z Drwęcka, zostaje po prostu wprowadzony w błąd.

Dużą nadzieją na poznanie kultury materialnej i duchowej zakonu krzyżackiego są badania nad budownictwem zamkowym, którym interesował się już, jak napisał autor, kronikarz Christoph Hartknoch, a także późniejsi kronikarze. Zainteresowania te przejęli po nich badacze historii. Wśród nich zabrakło jednak tak ważnych postaci, jak chociażby Johann Dewitz czy Benedict Christian Hermann z Elbląga, autorzy licznych rysunków miast i zamków z Prus ${ }^{10}$, których znakomita część zachowała się w Instytucie Sztuki Polskiej Akademii Nauk w Warszawie ${ }^{11}$. Ponadto warto wspomnieć o innej osobie, której zabrakło, a której wkład w badania nad Prusami przedkrzyżackim okazuje się niezwykle cenny dla kolejnych pokoleń archeologów i historyków. Mowa o poruczniku Johannie Michaelu Guise, który w latach 1826-1828 na zlecenie sztabu wojskowego inwentaryzował grodziska, sporządzając liczne szkice terenowe. Zachowały się one do dziś w archiwum Museum für Vor- und Frühgeschichte - Staatliche Museen zu Berlin jako część spuścizny dokumentowej dawnego Prussia-Museum w Królewcu ${ }^{12}$.

${ }^{8}$ Mirosław J. Hoffmann, $Z$ historii badań archeologicznych $w$ rejonie pól grunwaldzkich, [in:] Tradycje kulturowe i historyczne ziem pruskich. Krajobraz grunwaldzki $w$ dziejach polsko-krzyżackich i polsko-niemieckich na przestrzeni wieków. Wokół mitów i rzeczywistości, red. Jan GANCEWsKI, Olsztyn 2009, s. 146-149.

${ }^{9}$ Mirosław J. Hoffmann, Kazimierz Madela, Drwęck 1939 - ofiara złożona bóstwom czy morderstwo doskonałe?, Biuletyn Oddziału Warmińsko-Mazurskiego Stowarzyszenia Konserwatorów Zabytków, 2006, z. 4, s. 13-20.

${ }^{10}$ Max Toeppen, Die Elbinger Geschichtsschreiber und Geschichtsforscher in kritischer Uebersicht vorgeführt, Zeitschrift des Westpreussischen Geschichtsvereins, H. 32: 1892, s. 119-135.

${ }^{11}$ Wchodzą one w skład zdigitalizowanej dokumentacji fotograficznej sporządzonej w latach 2001-2005, wydanej przez IS PAN: Prusy Wschodnie - dokumentacja historycznej prowincji. Zbiory fotograficzne dawnego Urzędu Konserwatora Zabytków w Królewcu, oprac. Jan PrzYPKowsKi, Warszawa [2006] [CD-ROM].

${ }^{12}$ Tzw. Guise-Zettel. Na temat inwentaryzacji prowadzonej przez J.M. Guisego zob. Mirosław J. Hoffmann, Inwentaryzacje założeń obronnych na ziemiach pruskich w pierwszej połowie XIX w., [in:] Opusculum archaeologica. Opera dedicata in professorem Thaddeum Malinowski, red. Wojciech Dzieduszycki, Zielona Góra 2007, s. 153-160. 
W drugim rozdziale autor pochyla się nad Prusami przedkrzyżackimi. Opisując wpierw społeczeństwo Bałtów (Early Medieval Baltic Society, s. 43 n.), słusznie podważając dziewiętnastowieczne koncepcje o zacofaniu Prusów, dalej rozpatrując etymologię nazwy Prusy, opisując język (Etymology, Language and Society, s. 44-47), kulturę materialną i strukturę społeczną (Material Culture, Ethnicity and Social Structure, s. 47-49), choć tu głównie na podstawie źródeł archeologicznych, nie wykorzystuje stosunkowo licznych źródeł pisanych: relacji Wulfstana, kronik krzyżackich, źródeł normatywnych takich jak choćby nadania dla Prusów. Autor nie skorzystał też z nowszych, ważnych prac na ten temat Dariusza Adama Sikorskiego $^{13}$ i Grischy Vercamera ${ }^{14}$, przez co prezentowany w książce wykład na temat społeczeństwa Prusów jest niepełny. Trudno jednakże wymagać, aby krótka charakterystyka zawarta $\mathrm{w}$ trzech akapitach miała wyczerpywać temat. Znacznie więcej miejsca autor poświęca organizacji terytorialnej oraz szeregowi stanowisk archeologicznych - grodziskom, cmentarzyskom z obszarów plemiennych Prus (Strongholds and Settlement, s. 51-66; West Prussia, s. 53-55; East Prussia, s. 55-59). $\mathrm{Na}$ początku autor stawia tezę o tym, że zasięg poszczególnych terytoriów określany był przez lokowane na pograniczach obiekty warowne, przedstawiając ich krótką charakterystykę oraz używając wobec nich słowiańskiego określenia grody. Pozwalając sobie w tym miejscu na cytat, warto się zastanowić, czy taka konstrukcja zdania nie wnosi niepotrzebnego zamieszania, a w konsekwencji możliwości błędnego zrozumienia treści przekazu u anglojęzycznego czytelnika: „[...] fortified strongholds, named in Slavic languages as gród, gorod, gard and hrad. Prussian gro$d y$ were similar to those in neighbouring Masovia, Kuyavia and Lithuania” (s. 51). Czytelnik może błędnie zrozumieć, że termin gród funkcjonował w Prusach. Aby tego uniknąć, oprócz zaznaczenia (co autor zrobił), że jest to wyraz słowiański, mógł choćby wspomnieć, że pruskim odpowiednikiem tego słowiańskiego terminu jest pilis, co znajduje liczne potwierdzenia w materiale onomastycznym ${ }^{15}$.

Pruskie określenia jednostek terytorialnych nie są autorowi obce. Zna i używa w książce pojęcia najniższej jednostki osadniczej, jakim był pruski lauks, stosuje też określenie pulko, pruski odpowiednik łacińskiego territorium i słowiańskiego włość. Termin ten, popularny na terenie Sambii, nie jest jednak notowany na innych obszarach Prus. Brak go dla przykładu całkowicie w Pomezanii, gdzie adekwatne terytoria określano łacińskimi słowami terrae, terulla, districtus lub pro-

${ }^{13}$ Dariusz Adam Sikorski, Instytucje władzy u Prusów w średniowieczu (na tle struktury społecznej i terytorialnej), Olsztyn 2010; idem, Uwagi o strukturze społecznej Prusów we wczesnym średniowieczu, Zapiski Historyczne (dalej cyt. ZH), t. 69: 2004, z. 4, s. 7-26.

${ }^{14}$ Grischa Vercamer, Der Übergang der prußischen Stammeseliten in die Schicht der „Freien” unter der Herrschaft des Deutschen Ordens und der Kulturtransfer von der „deutschen” auf der prußische Kultur, [in:] Mittelalterliche Eliten und Kulturtransfer östlich der Elbe. Interdisziplinäre Beiträge zu Archäologie und Geschichte im mittelalterlichen Ostmitteleuropa, hrsg. v. Anne Klammt, Sébastien Rossignol, Göttingen 2009, s. 169-191; idem, Siedlungs-, Sozial- und Verwaltungsgeschichte der Komturei Königsberg in Preußen (13.-16. Jahrhundert), Marburg 2010.

${ }^{15}$ Vytautas MAžıulis, Prūsu kalbos etymologijos žodynas, T. 3, Vilnius 1997, s. 280-281; T. 4, Vilnius 1997, s. 66. 
vinciae albo niemieckim landt, gebit. Nie oznacza to, że określenie pulko nigdy na obszarze Pomezanii nie występowało, ale na pewno wskazuje na to, że na Sambii dawne struktury osadnicze utrzymywały się wyjątkowo długo (Sambia: a Regional Centre of Power, s. 59-62).

W książce znajdujemy też pewien niezawiniony przez autora błąd popełniony w stosunku do fragmentu zdobionej skrzyni drewnianej, który rzekomo miano znaleźć na grodzisku w Suszu (Rosenberg). Właściwym miejscem znalezienia zabytku jest jednak grodzisko nad jeziorem Silm w okolicach Kamionki (Klein Steinersdorf) ${ }^{16}$, niewłaściwą informację zaś podała Łucja Okulicz ${ }^{17}$, na którą też powołał się autor (s. 52). Podobnie rzecz się ma z połówką dirhama znalezionego na wspomnianym grodzisku nad jeziorem Silm. Autor z jednej strony błędnie pisze (s. 54), że grodzisko znajduje się na wyspie - właściwie to półwysep. Z drugiej strony powtarza za Wiesławem Skrobotem ${ }^{18}$, że z informacji archiwalnych wiadomo, jakoby moneta pochodziła z XI w., choć W. Skrobot nie podaje źródła tej „informacji archiwalnej”. Przypuszczalnie jednak mowa tu o sprawozdaniu z krótkich wykopalisk Paula Kumma prowadzonych 1 i 2 VI 1908 r. Szczęśliwie sprawozdanie zachowało się w odpisie Waldemara Heyma w Archiwum Muzeum Archeologicznego w Gdańsku ${ }^{19} \mathrm{i}$ w artykule tegoż z $1933 \mathrm{r}^{20}$, jednakże są tam tylko informacje „o połówce dobrze zachowanej srebrnej monety kufickiej” („wohlerhaltene Hälfte einer kufichen Silbermünze"), bez choćby najmniejszej wzmianki o jej chronologii. W publikacji znalazło się sporo błędów deklinacyjnych związanych z polskimi nazwami, np. zamiast „The stronghold at Kamionce” (s. 54) powinno być „The stronghold at Kamionka".

W dalszej części pracy omówiona została kwestia rodzimego wytwórstwa i kontaktów handlowych, słusznie wiązanych z rolą militarną lokalnych elit (The Trade in Luxuries and Craft Specialisation, s. 62-64; Militarism, s. 64-66). Autor opisuje towary, które przybywały za pośrednictwem Wikingów do portów w Prusach, i te, które były z nich wywożone. Handel morski Prusów poświadczają źródła pisane. Pewne kontrowersje może natomiast wzbudzać chronologia odkrytych w końcu XIX w. we Fromborku i Bągarcie rzekomych wczesnośredniowiecznych łodzi. W połowie lat pięćdziesiątych XX w. za sprawą Przemysława Smolarka w obiegu naukowym po-

${ }^{16}$ Władysław ŁĘGA, Kultura Pomorza we wczesnym średniowieczu na podstawie wykopalisk, Toruń 1930, s. 409, 428, tab. LXVIII, il. 442.

${ }^{17}$ Łucja Okulicz-Kozaryn, Życie codzienne Prusów i Jaćwięgów w wiekach średnich (IX-XIII w.), Warszawa 1983, s. 111.

${ }^{18}$ Wiesław Sквовот, Osadnictwo wczesnośredniowieczne w strefach pogranicznych Pojezierza Iławskiego, [in:] Pruskie baby kamienne. Fenomen kulturowy czy europejska codzienność?, red. Jerzy M. ŁAPO, Grzegorz BIAŁUŃsKi, Olsztyn 2007, s. 119, gdzie autor podaje: „Grodzisko zwane Kesselberg, usytuowane na półwyspie jeziora Silm, było prawdopodobnie obiektem wielofunkcyjnym. Poza funkcją obronną służyło również jako faktoria handlowa, a także ośrodek produkcyjny. Może o tym świadczyć archiwalna informacja o znalezieniu srebrnego dirhema z XI w."

${ }^{19}$ Muzeum Archeologiczne w Gdańsku, Silma, sygn. 46n/27.

${ }^{20}$ Waldemar Hеyм, Siedlungsgrabungen im Kreise Rosenberg, Heimatkalender der Kreis Rosenberg 1933, s. 58 . 
jawiło się przypuszczenie o pruskim pochodzeniu tychże łodzi. Z czasem stało się ono popularną hipotezą, którą A. Pluskowski za Łucją Okulicz podejmuje w swojej pracy (s. 62). Ostatnie badania wskazują jednak, że z dużym prawdopodobieństwem można przyjąć ich późnośredniowieczne lub nowożytne pochodzenie ${ }^{21}$.

Autor poświęca dość dużo miejsca charakterystyce pruskiej religii (Religion: the Key to Understanding Diversity within pre-Christian Prussia?, s. 66-68), krajobrazu sakralnego i kultu bóstwa "Curche” (The Goddess and the Lime-Tree, s. 68-69), wobec którego autor konsekwentnie używa formy żeńskiej, choć żadne ze źródeł nie traktuje jej jako bogini, w przeciwieństwie do litewskiej Laimy. Większość interpretacji związanych z identyfikacją „płciową” „Curche” ma związek jedynie z zauważalnym w niektórych miejscach powiązaniem hipotetycznych miejsc poświęconych bóstwu z późniejszym kultem Marii Dziewicy.

W książce rzecz jasna nie można było pominąć problematyki kamieni ofiarnych i tzw. bab pruskich (Carved Stones, s. 71-75). Autor dość niefortunnie tłumaczy tę nazwę na język angielski jako „stone women”22, nie wiedząc, że występujące w tym kontekście słowo baby pojawiło się za pośrednictwem języków ludów stepowych. Pochodzi ono z tureckiego słowa baba lub bal-bal, czyli „mąż”, „przodek” i wiąże się z podobnymi posągami ze stepów nadczarnomorskich ${ }^{23}$. Słowo to zawędrowało do języka polskiego nie później niż w XVI w., lecz Prusowie go nie używali. Także w naukowej literaturze niemieckiej nazwa ta nie funkcjonowała zbyt powszechnie. I choć sporadycznie używano slawizmu Baben, czy tłumaczenia tegoż jako Steinmütterchen lub Steinweiber, to zazwyczaj operowano w ich kontekście określeniem Steinbilde - czyli po prostu „posągi kamienne”. Można byłoby przejść dalej obok zaproponowanego przez autora określenia "stone women”, gdyby nie fakt, że autor uważa za najbardziej przekonujące, że są to właśnie figury żeńskich bóstw lub walkirii! Sugestywnym argumentem są dla autora wyobrażenia rogów. Dalej co prawda wspomina, że część z nich wyposażonych jest broń, choć szkoda, że nie widzi u nich także bardziej męskich cech, jak brody (Nipkowie-Susz, Jelitki) czy wąsy (Nipkowie-Susz, Barciany). Znajdujemy tu także literówki, a raczej błędy w odmianie nazw własnych, miejscowych i toponimów: „Bluźniercy” zamiast „Bluźnierca”, „Krolicza Góra” zamiast „Królicza Góra”, „Elanowce” zamiast „Elanowka”, „Glisna” zamiast „Glisno”, „Kretowinach” zamiast „Kretowiny”. Uzupełnienia wymaga także lista tzw. kamieni ofiarnych z ziem pruskich. Autor mówi o zidentyfikowanych 15 , ale na podstawie literatury można wskazać ich prawie

${ }^{21}$ Waldemar Ossowsкi, Z badań nad wrakami fromborskimi, [in:] Bałtowie i ich sasiedzi. Marian Kaczyński in memoriam, red. Anna Bitner-WróBlewsKa, Grażyna IwanowsKa (Seminarium Bałtyjskie, t. 2), Warszawa 2009, s. 579-594.

${ }^{22}$ Bardziej adekwatne wyjaśnienie znajdujemy w indeksie (s. 427): „Prussian «baby» (anthropomorphic carved stones)".

${ }^{23}$ Włodzimierz Demetry кiewicz, Figury kamienne t.zw. „bab” w Azyi i Europie i stosunek ich do mitologii słowiańskiej. (Altertümliche steinere Statuen, sog. „baby” [Steinmüterchen, Becherstatuen] und ihr Verhältnis zur slavischen Mythologie), Bulletin international de l'Académie des Scienses de Cracovie. Classe de Philologie. Classe d'Historie et de Philosophie, Cracovie 1910, s. 101. 
$80^{24}$. Pisząc o rytuale pogrzebowym i ofiarach $\mathrm{z}$ ludzi (Cemeteries and the Cult of the Dead, s. 75-80), autor podaje informację, jakoby kronikarz Mikołaj z Jeroschina wspominał o składaniu na stosie ze zmarłym także jego żony („his wife”, s. 78). Spoglądając w tekst kroniki, zauważamy pomyłkę A. Pluskowskiego, gdyż mowa w niej nie o żonie, ale o służącej - meide $e^{25}$.

W dalszej części pracy znajdujemy opis chrześcijańskiego pogranicza Prus. Dokonano tu podziału na trzy kluczowe obszary: Kałdus i ziemię chełmińską (s. 81-82), pogranicze galindzko-mazowieckie (s. 82-83) oraz na deltę Wisły (s. 83-85). Obszary te objęte były już od dawna misjami chrystianizacyjnymi (Missionary Activity in Prussia before Crusades, s. 85-88). Analizując misję biskupa Wojciecha, autor - za Leszkiem Słupeckim - stawia tezę o śmierci misjonarza w Kałdusie (s. 85), pomijając w tym miejscu całkowicie inne hipotezy - pomezańską i sambijską, do których nagle nawiązuje pod koniec książki (s. 369-370). Następnie przechodzi do krótkiego omówienia misji Brunona z Kwerfurtu, misji cysterskich i ruskich.

Trzeci rozdział poświęcony jest już stricte podbojowi ziem pruskich (The Ravages of Holy War. Crusade and Colonisation in the Thirteenth Century, s. 89-139). Autor opisuje wcześniejsze próby obrony ziem polskich przed najazdami pogan oraz ujarzmienia plemion pruskich i nikłe sukcesy $\mathrm{w}$ tym kierunku szeregu zakonów rycerskich. Dopiero zakon krzyżacki dzięki sprawnej propagandzie, wspieranej przez autorytet Stolicy Apostolskiej oraz zbrojne ramiona krzyżowców z Niemiec, Polski i Czech, zdołał osiągnąć zamierzony sukces (s. 89-91). Jak dowodzi autor, sukces ów wiązał się nie tylko z ciągłymi najazdami, lecz przede wszystkim $\mathrm{z}$ tworzeniem $\mathrm{z}$ postępem wojsk stałego zaplecza w postaci grodów, często wznoszonych na miejscu dawnych pruskich warowni, z których z czasem wyrosły murowane zamki (por. szczególnie: The earliest Strongholds and Castles built by the Teutonic Order in Prussia, s. 97-101). Grody i zamki stanowiły także zaplecze dla kolonizacji podbitych ziem, w której uczestniczyli zarówno rycerze niemieccy jak i ludność chłopska oraz mieszczanie ze Śląska, ziemi chełmińskiej, Brandenburgii, Lubeki. W sumie było to około 10-15 tysięcy osadników do końca XIV w. Część lokowanych przez Krzyżaków miast otrzymywało nazwy przeniesione z terenów, z których przybywali osadnicy. Przykładem może być Ostróda (Osterode) czy Zalewo (nie „Zalewa”, jak pisze autor) - dawne Saalfeld, których nazwy nawiązują do miast znajdujących się w Niemczech. Obok obcych trzon osadników stanowili chłopi i wolni pruscy, którym autor poświęca kilka zdań na stronie 104, by temat ten rozwinąć następnie w dalszej części pracy (Colonisation and the Population of Fourteenth-Century Prussia, s. 144-177), słusznie zauważając, że Zakon starał się

${ }^{24}$ Robert KLIMEK, Kamienie kultowe na ziemiach pruskich, [in:] Kamienie w historii, kulturze i religii, red. Robert KLIMEK, Seweryn SzCZEPAŃsKI, Olsztyn 2010, s. 62-109.

${ }^{25}$ „Hîvon das pflegelîch geschach, // sô man dî edelin sterbin sach, // daz man wâpin unde pfert, // knechte, meide [podkreślenie - S.S.], cleidir, wert, // jaithunde und vedirspil // und andirs gezûgis vil, // daz man zu hêrschaft nante, // mit den tôdin brante" (Di Kronike von Pruzinlant des Nicolas v. Jeroschin, hrsg. v. Ernst STREHLKe, [in:] Scriptores rerum Prussicarum, Bd. 1, hrsg. v. Theodor Hirsch, Max Töppen, Ernst StrehlKe, Leipzig 1861, s. 349, w. 4069-4076). 
osłabiać ich potencjał polityczno-społeczny przez politykę przesiedleń. Przykład osiedlania Bartów na obszarze Pogezanii przytoczony przez autora można także uzupełnić przykładami przesiedleń Jaćwięgów na relatywnie spokojny obszar pomezańsko-sasiński.

Zderzenie kulturowe nowych osadników $\mathrm{z}$ autochtonami skutkowało pojawianiem się wielu elementów typowych dla tej części Europy. Autor szeroko rozpatruje ów problem w podrozdziale The Archaeology of Prussian Colonisation (s. 104-112). Analizując problematykę miejscowego wytwórstwa ceramiki, funkcjonowanie najwcześniejszych form pieniądza, wskazuje na możliwości datacji poszczególnych stanowisk i obiektów za ich pomocą. Dodatkowo dzieli się swoimi refleksjami na temat użyteczności dendrochronologii oraz analiz form cegieł używanych w budowie zamków. Dalej znajdujemy opisy poszczególnych zamków i grodów powstałych w trakcie podboju na obszarze ziemi chełmińskiej (Starogród, Chełmno, Toruń, Grudziądz, Radzyń Chełmiński, Pokrzywno, Rogoźno - błędnie zapisane „Rogózno”, Papowo Biskupie, Pień, Bachotek; s. 112-119), Powiśla i Pomezanii (m.in. Kalwa - błędnie zapisana jako „Kalwie”, Kwidzyn, Dzierzgoń, Gniew, Zantyr - Biała Góra, Elbląg; s. 119-126). W końcowych podrozdziałach autor opisuje podbój dalszych terytoriów plemiennych: Warmii, Natangii, Sambii, ziemi lubawskiej, Galindii i Jaćwieży, kończąc rozdział konkluzjami (s. 127-139).

Czwarty rozdział pt. A Land of Red Castles autor na początku poświęca problematyce struktur administracyjnych wprowadzonych przez zakon krzyżacki i budowie potęgi jego władztwa nad Bałtykiem, które w swojej idei nawiązywać miało do Cesarstwa Niemieckiego (s. 140-141). Znajdujemy tu krótką charakterystykę znanych ze średniowiecznych źródeł urzędów krzyżackich, począwszy od najwyższego, jakim był wielki mistrz, do tych niższej rangi. W większości przypadków autor przytacza odpowiedniki angielskie niemieckich określeń urzędów względnie ich charakterystykę. W przypadku pojęcia Kammerämter znajdujemy polski odpowiednik „kumornictwa” [sic!], brak zaś angielskiego odpowiednika bailiffs (s. 142). Dalej autor opisuje miejsce pruskich autochtonów w społeczeństwie i strukturach władztwa krzyżackiego (s. 144-147). Jak na tytuł rozdziału przystało, dalsza jego część poświęcona jest tematyce zamków krzyżackich. Szczególnie szeroko autor omawia zamek w Malborku (s. 176-186), ale też zamki budowane na pograniczu ze Słowiańszczyzną (s. 190-193) i na obszarze wielkiej puszczy (s. 187-190). Tu wśród kilku obiektów pojawia się także nadal dokładnie niezlokalizowany i wciąż wzbudzający kontrowersje gród/zamek Weißenburg. Autor opowiada się za jego identyfikacją z Wyszemborkiem. Brakuje jednak szerszych wyjaśnień, dlaczego akurat ta lokalizacja okazała się dlań najbardziej przekonująca ${ }^{26}$.

Trzeba się zgodzić z autorem, że oprócz funkcji fiskalnej, militarnej i władczej konwenty stanowiły również centra życia duchowego oraz propagowania ideologii

${ }^{26}$ Ostatnio też, niezależnie od A. Pluskowskiego, do lokalizacji tej przychylono się w: Jarosław OścıŁowski, Jeszcze w sprawie lokalizacji Wallewony-Wisenburga, Pruthenia, t. 8: 2013, s. 271-286. Tam też szeroki przegląd wcześniejszych prób lokalizacji. 
świętej wojny (za tytułem podrozdziału: The Convents as Centres of Spiritual Life and Promoters of the Ideology of Holy War, s. 156 n.). Omawiając kaplice zamkowe, autor wskazuje na ich klauzurowy charakter zagwarantowany głównie dla członków i gości konwentu. Przy zamkach często znajdowały się kościoły. Jednakże przykład Dzierzgonia, gdzie u podnóża zamku komturskiego od średniowiecza znajdował się kościól, a który według autora pełnił zarówno funkcję kościoła parafialnego, jak i zamkowego, nie jest do końca trafny (s. 156-157). Zarówno ze źródeł krzyżackich $^{27}$, jak i późniejszych wiemy o istnieniu kaplicy konwentualnej na zamku ${ }^{28}$.

Ważnym aspektem władzy zakonu krzyżackiego była polityka fiskalna. Autor poświęca temu zagadnieniu kilka stron (Money and the Economic Identity of the Teutonic Order, s. 172-175). Opisuje zakonne mennice, politykę pieniężną w XIII-XV w., charakteryzuje monety bite przez Krzyżaków oraz wspomina o skarbach z czasów panowania zakonu krzyżackiego. Powołując się na publikację Zofii Januszkiewicz i Romualda Odoja z 1997 r., A. Pluskowski pisze, że na obszarze województwa olsztyńskiego/warmińsko-mazurskiego (właściwie autorzy piszą o „obszarze państwa krzyżackiego”) zanotowano ponad 30 skarbów z czasów krzyżackich. Choć Z. Januszkiewicz i R. Odoj piszą o niecałych 30 znaleziskach skarbów ${ }^{29}$, to niewątpliwie od roku ich publikacji liczba skarbów oraz wiedza o innych - zapomnianych - nieco się poszerzyła. Dla przykładu można podać niedawne odkrycie skarbu krzyżackiego w Karolewie koło Susza oraz znalezienie w archiwaliach informacji o skarbie z Tułodziadu (Taulensee) ${ }^{30}$.

Przechodząc ponad rozdziałem dotyczącym tworzenia miast w państwie krzyżackim jako centrów handlu międzynarodowego (From Colonisation to Urbanisation - Towns and International Trade, s. 196-245), zatrzymajmy się przy rozdziale szóstym (Converting Prussia. The Christianisation of the Teutonic Order's State, s. 246-293) i problematyce związanej z procesem nawracania ludności pruskiej. W podrozdziale Inpossing a Parish System on Prussia autor wraca do zagadnienia poruszanego wcześniej, mianowicie działalności chrystianizacyjnej prowadzonej przez cystersów i biskupa Chrystiana, z którymi to działaniami mógł się wią-

\footnotetext{
${ }^{27}$ Das grosse Ämterbuch des Deutschen Ordens, hrsg. v. Walther Ziesmer, Danzig 1921, s. 133 n.

${ }^{28} \mathrm{~W}$ latach $1720-1724$ reformaci z Dzierzgonia otrzymali prawo do pozyskiwania materiału budowlanego w celu budowy klasztoru „ex ruderibus kaplicy zamkowej czyli kościoła krzyżackiego na zamku kiszporskim”. Por. dokumenty w: Alojzy Szorc, Dzierzgoń. Od początków do dni naszych: 1249-1998, Dzierzgoń 1998, nr 15, s. 264-265; nr 17, s. 269-271; też s. 113. Wiadomo, że nie może tu być mowy o kościele parafialnym przy zamku, gdyż ten pełnił wówczas funkcję miejskiego kościoła. Został on odbudowany po pożarze w 1647 r. i konsekrowany 25 X 1682 r. Pełnił funkcję głównej świątyni miasta.

${ }^{29}$ Zofia Januszkiewicz, Romuald OdoJ, Skarb monet krzyżackich $z$ Gródek, Rocznik Olsztyński, t. 17: 1997, s. 206.

${ }^{30}$ Michał Zawadzki, Skarb szelagów krzyżackich $z$ Karolewa koło Susza, [in:] Średniowieczne skarby $z$ Pojezierza Iławskiego w zbiorach Muzeum Warmii i Mazur, red. Elżbieta Jelińska, Olsztyn 2013, s. 253-289; Seweryn SzCZEPAŃski, Skarb monet $z$ Tułodziadu $w$ świetle archiwaliów dawnego Prussia-Museum. Zapomniany świadek batalii grunwaldzkiej?, ZH, t. 80: 2015, z. 1, s. 7-11; Zofia JANUSZKIEwICZ, Skarby monet w zbiorach Muzeum Warmii i Mazur w Olsztynie, Olsztyn 2001.
} 
zać proces wznoszenia pierwszych przybytków chrześcijańskich na terenie Prus. Najwcześniej potwierdzone kościoły nie pochodzą dopiero z 1249 r., ponieważ już w 1236 r. w Postolinie na pruskiej ziemi „Aleym” istniał kościół parafialny. Należały do niego dowodnie wsie Wadkowice (Gross Watkowitz), Mirowice (Mirahnen) oraz "Sircoy”, a zapewne także inne sąsiednie osady, gdyż dokument z 1236 r. informuje tylko o prawie do pobierania dziesięciny $\mathrm{z}$ wymienionych wsi przez Dietricha von Tiefenau ${ }^{31}$. Postolin pojawia się $\mathrm{w}$ tekście traktatu dzierzgońskiego w 1249 r. wśród innych miejscowości, w których Prusowie mieli wznieść kościoły. Uległ on być może zniszczeniu podczas pierwszego powstania pruskiego, ale nie można się zgodzić z autorem, który twierdzi, jakoby wszystkie kościoły wymienione w 1249 r. miały być odbudowane po wcześniejszym zniszczeniu (s. 252). Wiele kościołów wzniesiono w miejscach, gdzie ich wcześniej nie było. Stało się to zgodnie z literą traktatu, który dosłownie mówi o „wybudowaniu” („edificabunt”) kościołów na obszarze Pomezanii, Warmii i Natangii w celu zapewnienia posługi kapłańskiej dla neofitów ${ }^{32}$. Nie jest też prawdziwe stwierdzenie, że wymienio-

${ }^{31}$ Urkundenbuch zur Geschichte des vormaligen Bisthums Pomesanien, hrsg. v. Hermann CRAMER, Marienwerder 1885, Nr. I.

${ }^{32}$ PrUb., Bd. 1, H. 1, Nr. 218. Pewne zamieszanie w kwestii „odbudowania” kościołów wprowadził już Karol Górski, pisząc, że „[...] w 1249 r. Pomezanowie, którzy byli chrześcijanami, zobowiązali się odbudować [podkreślenie - S.S.] 13 zniszczonych kościołów [...]” [pogrubienie, także w dalszej części przypisu - S.S.] (Karol GóRsKI, Zakon krzyżacki a powstanie państwa w Prusach, Warszawa 1977, s. 40). W podobnym tonie wypowiadał się Gerard Labuda: „Obiecali oni [Prusowie - S.S.] też odbudować 22 kościoły zburzone w czasie wojny na terenie Pomezanii, Warmii i Natangii” (Gerard Labuda, Marian BIskup, Dzieje zakonu krzyżackiego w Prusach. Gospodarka - społeczeństwo - państwo - ideologia, Gdańsk 1986, s. 147). Alojzy Szorc pisał z kolei: „Prusowie zobowiązywali się do Zielonych Świątek tegoż 1249 r. odbudować aż trzynaście kościołów jakie zburzyli w krainie Pomezanów [...]" (A. Szorc, op.cit., s. 27). Podobnie: Stefan Chojnecki, Wojciech MikuŁa, Dariusz SoкоLı́́sкi, Podbój terytoriów plemion pruskich przez Zakon Krzyżacki. Walki Zakonu Krzyżackiego z Litwa i Polska do 1525 roku, [in:] Działania militarne w Prusach Wschodnich, red. Wiesław WRóBLEWSKI, Warszawa 1998, s. 51; oraz archeolog Łucja Okulicz: „Prusowie zobowiązywali się wystawić do Zielonych Świątek trzynaście kościołów w Pomezanii [...] - wszędzie tam, gdzie były już wcześniej zbudowane, a w czasie wojny - spalone" (Łucja Okulicz, Dzieje Prusów, Wrocław 2000, s. 363). Z przytaczanych cytatów (a można by je jeszcze mnożyć) wynika, że autorzy powtarzając ów nieznajdujący poparcia w tekście traktatu pogląd o „odbudowywaniu zniszczonych kościołów”, częstokroć jeszcze bardziej ubarwiali mimowolnie negatywne konsekwencje powstania wobec kiełkującego chrześcijaństwa. Problematyczne jest także samo, chyba najbardziej popularne, tłumaczenie dokumentu autorstwa Alojzego Szorca, opublikowane na stronie domwarminski.pl, gdzie autor fragment oryginalnego źródła: „Promiserunt etiam illi de Pomezania, quod infra proximum Pentecosten ecclesias edificabunt in locis inferius nominantis”, tłumaczy jako: „Prusowie z Pomezanii przyobiecali, że do najbliższych Zielonych Świąt odbudują zburzone przez siebie kościoły w dwunastu miejscowościach", gdzie słowo „edificabunt” zostało niesłusznie przetłumaczone jako „odbudują" zamiast „wybudują", dodając także informację o „dwunastu miejscowościach”, która w zapisie nie występuje. Zresztą słowo „in locis” powinno ponadto być tłumaczone jako „w miejscach”. W poprawionej wersji tłumaczenia A. Szorca, które przedstawił ostatnio Andrzej Radzimiński (idem, Chrystianizacja i ewangelizacja Prusów. Historia i źródła, Toruń 2011, s. 86), słowo „odbudują” zamieniono na „zbudują”, ale pomijając rzeczywiste brzmienie źródła, powtórzono za A. Szorcem tłumaczenie „in locis”, jako „w miejscowościach” zamiast właściwego - w miejscach. 
ne w traktacie kościoły były wznoszone przy krzyżackich grodach (s. 252). Wiele z nich powstało na obszarze pruskich osad lub ogólnie na obszarach wiejskich, bez podania w powyższym źródle konkretnej ich lokalizacji ${ }^{33}$.

Pisząc o nawracaniu pogan i tworzeniu nowej sfery sakralnej, autor dokonuje bardzo istotnego spostrzeżenia, że na obszarze Prus nie mamy pewnych dowodów na to, że chrześcijańskie kościoły wznoszono w miejscach dawnych sanktuariów (s. 282). Można jednak, jak pisze autor, zauważyć, że zabytki dawnej kultury duchowej ludów podbitych wykorzystywano do wzmocnienia ideologicznego zwycięstwa chrześcijańskiego Boga. Dla przykładu wystarczy podać przypadek wmurowania $\mathrm{w}$ fundament czternastowiecznego kościoła w Prątnicy kamiennego posągu - tzw. pruskiej baby, który miał odzwierciedlać triumf chrześcijaństwa nad leżącym u jego stóp pogańskim idolem. Podobnie rzecz się miała w przypadku umieszczenia pogańskiego posągu w ścianie klasztoru reformatów w Dzierzgoniu. Klasztor ten jednak nie został wzniesiony w XVI w., jak czytamy w książce (s. 283), ale w latach dwudziestych XVIII stulecia ${ }^{34}$. Zabytek ten, podobnie jak inne związane $\mathrm{z}$ dawną pruską kulturą duchową, zachował się w pamięci lokalnej i folklorze jako „święte”, „diabelskie”, „pogańskie” kamienie. Autor wymienia kilka z nich, jak np. te z Tolkmicka, Grundfeld w Natangii czy Długiego Kąta z okolic Pisza (tu błędnie zapisano „near Pisza”- zamiast „near Pisz”, s. 282). Wiele elementów pogańskiego oglądu świata mimo starań władz kościelnych, wznoszenia świątyń w nowo lokowanych wsiach (patrz podrozdział Rural Churches: Christianisation through Colonisation, s. 283-286) i kar, jakie spotykały ludność pielęgnującą w zaciszu dawne praktyki, przetrwało dość długo wśród ludności wiejskiej. W podrozdziale poświęconym temu problemowi (Beyond the Church: the Continuation of pre-Christian Practices, s. 287-291) autor przytacza szereg przykładów ze źródeł pisanych i archeologicznych, które udowadniają, że Prusowie kontynuowali w nieco zmienionej formie praktyki pogrzebowe i kult przodków.

W siódmym rozdziale: From Forest to Field. The Changing Environment of Medieval Prussia, którego współautorem jest Alexander Brown, znajdujemy szereg szczegółowych informacji na temat przyrody Prus. Na wstępie rozdziału autor postarał się o bardzo zgrabny opis pruskich lasów, jezior i rzek oraz warunków naturalnych ziem między Wisłą i Niemnem (s. 294-297). Z metodologicznego wstępu (Studying the Crusades from an Environmental Perspective, s. 297-303) dowiadujemy się, jakich efektów oczekiwał autor, analizując pozyskane w czasie prac archeologicznych oraz znane $\mathrm{z}$ literatury dane paleobotaniczne i archeozoologiczne, rozszerzając je o analizę źródeł pisanych, ikonograficznych i kartograficznych oraz

${ }^{33}$ Reinhard Wenskus, Über die Bedeutung des Christburger Vertrages für die Rechts- und Verfassungsgeschichte des Preussenlandes, [in:] Studien zur Geschichte des Preussenlandes. Festschrift für Erich Keyser zu seinem 70. Geburtstag dargebracht von Freuden und Schülern, hrsg. v. Ernst BAHR, Marburg 1963, s. 97-118; Seweryn SzczePański, Chomor sancti Adalberti (1249) a możliwości lokalizacji terenowej wybranych kościołów Pomezanii, Komunikaty Mazursko-Warmińskie, 2013, nr 1 (279), s. 19-45.

${ }^{34}$ Zob. przyp. 28. 
o dane $\mathrm{z}$ dziedzin, takich jak geologia, gleboznawstwo i chemia. $\mathrm{W}$ rozdziale na podstawie analiz palinologicznych udało się częściowo odpowiedzieć na pytania dotyczące postępów osadnictwa na obszarze Prus, wpływu podboju dokonanego przez zakon krzyżacki na ubytek drzewostanu (s. 303-309), roli, jaką odgrywało w Prusach łowiectwo (s. 309-313, 321, 327-328, 335-336), jakie zaczęto wprowadzać uprawy (s. 313-319) oraz jak bardzo zmieniła się dieta mieszkańców tego obszaru. Sporo też wiadomości znajdziemy na temat hodowli koni zarówno przez dawnych Prusów, jak i Krzyżaków (s. 319-320 n.). Dzięki badaniom przyrodniczym udało się również ustalić, jaki klimat panował w Prusach w okresie średniowiecza. Optimum klimatyczne miało przypaść między IX a XII stuleciem, charakteryzując się cieplejszymi zimami i dłuższym okresem wegetacji. Ochłodzenie klimatu zaczęło następować po 1300 r. (s. 301).

Ważne z perspektywy przyrodniczej są także podrozdziały poświęcone jeziorom, rzekom, stawom rybnym i związaną z nimi gospodarką oraz ogólnie hydrologii Prus (s. 323-333). Pojawiają się tu kolejny raz błędne zapisy (s. 326-327): „Lidzbark Wielski” zamiast Lidzbark Welski, „River Wkrze” zamiast „river Wkra”, „Wądołku” zamiast Wądołek, „Szczytnie” zamiast Szczytno oraz „Montowe Małe” zamiast Montowy Małe (s. 332).

W ósmym, ostatnim rozdziale autor zgodnie z tytułem: The End of Holy War (s. 337-374) wskazuje, jakie znaczenie dla zakonu krzyżackiego miało przejście od „świętej” wojny do wojny „świeckiej” (From Holy War to Secular War, s. 337-340) i zaangażowanie się w konflikt z chrześcijańską Litwą i Polską. Nadmienić tu wypada, że wielki książę litewski Witold, syn Kiejstuta, nie był, jak pisze autor (s. 337), bratem rodzonym Władysława Jagiełły syna Olgierda, ale jego kuzynem - bratem stryjecznym. Także ponownie użyto błędnych form nazw miejscowych. Zamiast „in Plemiętach” autor powinien zastosować zapis „in Plemięta”, podobnie rzecz się ma wobec zapisu „in Nawrze-Bogusławkach” zamiast właściwego „in Nawra-Bogusławki”. Błędnie też autor zapisuje imię Juliana Ursyna Niemcewicza jako „Urzyn” (s. 371). Błędna jest też data wojny polskiego króla Stefana Batorego z Gdańskiem, która według autora toczyła się w latach 1577-1588 (s. 361). Dość wspomnieć, że Batory zmarł 12 XII 1586 r., a wojna toczyła się w latach 1576-1577.

O ile reformacja i sekularyzacja zakonu krzyżackiego w Prusach zakończyła etap przejścia Prus z epoki średniowiecza w epokę nowożytną, to należałoby jednak w tym miejscu wyraźnie powiedzieć (czego autor nie zrobił), że sekularyzacja dokonana przez Albrechta Hohenzollerna nie położyła kresu istnienia korporacji. Słusznie jednak zauważono w książce, jak wyraźny ślad w mentalności potomnych zostawiły czasy panowania zakonu krzyżackiego. Autor pisze o swoistym krzyżackim renesansie, którego upatrywać należy w dziewiętnastowiecznym romantycznym zainteresowaniu historią średniowiecznych Prus. Skutkowało to nie tylko wznowieniem badań nad zakonem krzyżackim i Prusami, lecz także próbami odrodzenia architektury w postaci neogotyckiego stylu, w jakim wznoszono 
kościoły oraz budynki użyteczności publicznej, podejmowanymi próbami renowacji i regotyzacji szeregu zamków - w tym także prywatnych (vide Szymbark) oraz tworzenia - można by rzec - „sanktuariów pamięci” w postaci muzeów od szczebla regionalnego począwszy, a na monumentalnych założeniach takich jak zamek w Malborku skończywszy. Słusznie autor zauważa, że współcześnie zakon krzyżacki i Prusowie cieszą się coraz większym zainteresowaniem w Niemczech, Polsce, na Litwie i w Rosji. Powstają kolejne wystawy poruszające problematykę Prusów, Prus i zakonu krzyżackiego, pod Grunwaldem corocznie spotykają się grupy rekonstrukcyjne w celu odegrania inscenizacji bitwy. Dość długą tradycję mają też próby przywracania pamięci o miejscach męczeństwa świętego Brunona i świętego Wojciecha (s. 369-371). Jest to temat na całkowicie oddzielne studium, bo koncepcji dotyczących możliwych miejsc śmierci obu misjonarzy w ostatnim czasie namnożyło się niezwykle dużo. Podobnie od jakiegoś czasu powstaje coraz więcej grup rekonstruujących język pruski, pruskie obyczaje oraz gromadzących ludzi, którzy... uważają się za Prusów! Działalność tego rodzaju społeczności wydaje się też niezwykle interesującym zjawiskiem tożsamościowo-socjologicznym.

Podsumowując książkę The Archaeology of the Prussian Crusade, można stwierdzić, że czytelnik dostaje w swoje ręce napisaną dobrym językiem syntezę dziejów Prus średniowiecznych zawierającą się zasadniczo w okresie od XIII do XVI w. Autor przedstawia zasiedlające ten teren plemiona pogańskie, prezentuje, jak i na jakich zasadach ideologicznych przebiegał ich podbój oraz do czego ostatecznie doprowadził. W książce nie znajdziemy emocjonalnych tyrad gloryfikujących bohaterskość oporu Prusów, pejoryzacji zakonu krzyżackiego i melioryzacji Polski. Autor prowadzi swoją refleksję nad dziejami tej części Europy w sposób wyważony.

W kilku przypadkach autor niestety niepoprawnie interpretował podane mu informacje, zdarzało się też, że aż nadto bezkrytycznie powtarzał błędne opinie innych. Każdy przecież, kto ma choćby niewielkie pojęcie na temat znalezisk importów monet arabskich w Prusach, wie, że jedenastowiecznych dirhamów po prostu tu nie ma! Choć jeszcze w $\mathrm{X}$ w. docierały one na pogranicze słowiańskopruskie $^{35}$. Zdarza się, że arabskie monety występowały w skarbach datowanych nawet na drugą połowę XI stulecia, ale pochodziły one zazwyczaj z IX, a nawet VIII w. ${ }^{36}$, co świadczy o tym, jaką wartość miało orientalne srebro. A. Pluskowski

\footnotetext{
${ }^{35}$ Mateusz Bogucki, Dorota Malarczyк, Ewa Marczak, Skrab dirhamów zX wieku z grodziska $w$ Truszkach Zalesiu, pow. Kolno, woj. podlaskie, Wiadomości Numizmatyczne, R. 49: 2005, z. 2 (180), s. 187-188; Mateusz BogUCKI, Coin finds in the Viking-Age emporium at Janów Pomorski (Truso) and the „Prussian Phenomeon", [in:] Money Circulation in Antiquity, the Middle Ages and Modern Times: Time, Range, Intensity, ed. Stanisław Suchodolski, Warsaw-Cracow 2007, s. 79-108.

${ }^{36}$ Przykładem mogą być dwa skarby odkryte na obszarze południowej Pomezanii: w Mózgowie oraz Olbrachtówku, gdzie z monetami arabskimi z VIII-IX w. znajdowały się monety zachodnioeuropejskie nawet z połowy XI w., zob. Dorota MaLarczyк, Monety arabskie w skarbie z Mózgowa, [in:] Średniowieczne skarby $z$ Pojezierza Iławskiego, s. 140-157; eadem, Monety arabskie $w$ skarbie $z$ Olbrachtówka, [in:] ibid., s. 214-220. Nie jest to zresztą zjawisko odosobnione tylko dla terenów północnych. „Długie trwanie” (aczkolwiek nie tak długie jak w Prusach) w obiegu arabskiego sre-
} 
niestety czasem błędnie interpretuje tezy niektórych autorów, nie rozszerza swojej wiedzy o nowszą literaturę, zdarza się, że niedokładnie tłumaczy zapisy źródłowe oraz popełnia pomyłki $w$ datach i zapisach nazw miejscowych, dokonuje zbyt dowolnych tłumaczeń na język angielski i staje się mimowolną ofiarą błędów, dokonując nieprawdziwych interpretacji - casus „stone women”. Pewną wadą książki jest także jej konstrukcja. Kilka wątków wędruje w licznych rozdziałach. Raz poruszona kwestia nie zostaje dokończona w poświęconym jej rozdziale, lecz bywa, że znajdujemy ją w dalszej części pracy. Mimo owych wad zauważonych w książce, choć głównie skupiałem się na tematyce dotyczącej Prusów, jest to praca mająca wartość poznawczą dla anglojęzycznego czytelnika chcącego się zapoznać z historią Bałtów, Prusów oraz zakonu krzyżackiego. Jest przy tym chyba pierwszą tak szeroko poruszającą temat Prus plemiennych i Bałtów po publikacji, którą 15 lat temu wydał w języku angielskim Endre Bojtár ${ }^{37}$. Pozostaje też nadzieja, że autor jako ceniony wykładowca uniwersytecki przyjmie powyższe uwagi i wykorzysta je w kolejnych publikacjach oraz w pracy dydaktycznej.

dr Seweryn Szczepański

Ośrodek Badań Naukowych im. Wojciecha Kętrzyńskiego w Olsztynie

e-mail: seweryn.szczepanski@op.pl

bra znajdujemy także na terenach sąsiadujących $\mathrm{z}$ arabskimi kalifatami, choćby na obszarze Gruzji, gdzie spotykamy w jednych skarbach monety $\mathrm{z}$ lat $699 / 700$ oraz 833 , por. $\mathrm{T}^{\mathrm{e}}$ amar Lomouri, $P^{\mathrm{e}}$ ulis mimok'ceevis istoriisat'vis šua saukuneebis sakart'veloši, ed. T'inat' in K' UT'ELIA, Tbilisi 2005, s. 16-46 (streszczenie: On the History of Monetary Circulation in medieval Georgia, s. 141-145).

${ }^{37}$ Endre Bojtár, Foreword to the Past: A Cultural History of the Baltic People, Budapest 1999. 